\title{
Elektro Çekim Yöntemi ile Çörek Otu ve Yün Yağı Takviyeli Yara Örtüsü Geliştirilmesi
}

\author{
Black Seed and Wool Oil (Lanolin) Reinforced Wound Dressing Development by Electrospinning \\ Method
}

\author{
Erdem ŞAHİN (D), Canberk ELMALI (D), Derya Saltık ÇíRKİN (D), Muhammet UZUN (D) \\ Marmara Üniversitesi, Teknoloji Fakültesi, Tekstil Mühendisliği,34722, İstanbul/TÜRKIYE
}

Öz

Hayvansal liflerin en önemlisi olan yün 100\% ya da karışım olarak kullanılmaktadır. Yapısal özelliklerinden dolayı günlük hayatta kullanıldığı gibi teknik tekstil uygulamaları da vardır. Bu çalışma kapsamında yün üretimi sırasında açığa çıkan yan ürün (by-product) olan yün yağı (lanolin) katma değeri yüksek tıbbi tekstil üretiminde kullanılmıştır. Yapılan üretim sırasında geliştirilen yara örtüsüne ek özellik katmak için çörek otu tohum yağı takviye edici olarak kullanılmıştır. Literatürde açıkça belirtildiği üzere çörek otu tohumları ve çörek otu yağı insanlar üzerinde denenmiş ve insan sağlığına pozitif etkisi kanıtlanmıştır. Çörek otunun hastalıkları tedavi ve önleme dışında yara iyileştirme etkisinin olduğu gözlenmiştir. Yara iyileşme süreci birbirini izleyen karışık bir süreçtir ve doğru içerikli ve özellikli yara örtüsünün kullanılması bu süreci kısaltacaktır. Çeşitli yara örtüsü tipleri vardır, bunlar; anti bakteriyel, aljinat, kompozit, hidrojel vb. Son yıllarda yapılan araştırmalar electrospining tekniği ile üretilen nanolif yara örtülerinin önemini göstermektedir. Elektro çekim tekniği genel olarak, belirli derişimlerde oluşturulan polimer çözeltisine küçük akış hızları altında, kV düzeyinde bir elektrik kuvveti uygulayarak polimer çözeltiden nano boyutlu liflerin oluşmasına imkân sağlamaktadır. Bu çalışmada elektro eğirme tekniği ile yün yağı ve çörek otu yağından nanolif yapılı yüzey üretilmiştir. Yün yağı ve çörek otu yağının yanında çözücü olarak Diklorometan ve Dimetilformamid, polimer olarak Polilaktik asit, kullanılmıştır. Değişik konsantrasyonlarda; PLA/Yün/Çörek otu yağı karışımı sırasıyla 99/0.5/0.5, 98/1/1, 96/2/2, 90/5/5 ve 80/10/10 oranlarında çözeltiler oluşturulmuştur. Yün ve çörek otu yağ1, çözelti içerisinde 50/50'lik oranda kullanılmıştır. Oluşturulan çözeltilerin üretime başlamadan önce viskozite ölçüm cihazı ve iletkenlik ölçüm cihazı ile akışkanlık ve iletkenlik değerleri ölçülmüştür. Sonuç olarak elektro eğirme yöntemiyle yün ve çörek otu yağı karışımından başarılı bir şekilde nanolif esaslı yapı elde edilmiştir.

Anahtar Kelimeler: Nanolif, elektro-çekim yöntemi, çörek otu yă̆ı, yün yăğ, by-product, yara örtüsü

\begin{abstract}
Wool, which is the most important of animal fibers, is used as $100 \%$ or as a blend in textile protection. Thanks to its structural features, there are technical textile applications as well as used in daily life. Within the scope of this study, wool oil (lanolin), a by-product occurs during the wool processing, was used in the production of medical textiles with high added value. Black seed oil was used as a supplement to add further properties to the developed wound dressings. As clearly stated in the literature, Nigella Sativa seeds and Nigella Sativa oil have been tested on humans and their positive effect on human health has been well established. It has been observed that black seed has a wound-healing effect apart from the treatment and prevention of diseases. The wound healing process is a successive mixed process, and the use of wound dressing which has a correct content and feature will shorten this process. There are various types of wound dressings, these are; antibacterial, alginate, composite, hydrogel etc. Recent researches show the importance of nanofiber wound dressings produced with the electrospinning technique. The electrospinning technique generally enables the formation of nanoscale fibers from the polymer solution by applying an electric force at the $\mathrm{kV}$ level under small flow rates to the polymer solution formed at certain concentrations. In this study, a nanofiber structure was developed and produced from wool oil and black seed oil with the electrospinning technique. In addition to wool oil and black seed oil, Dichloromethane and Dimethylformamide were used as solvents, and Polylactic acid was used as the polymer. In different concentrations; PLA / Wool / Black seed oil mixture solutions were formed in the ratio of 99/0.5/0.5, 98/1/1, 96/2/2, $90 / 5 / 5$ and 80/10/10 respectively. Wool and black seed oil are applied to the solution at a rate of 50/50. Fluidity and conductivity values of
\end{abstract}


the formed solutions were measured with the viscosity meter and conductivity meter before starting production. As a result, a nanofiber-based structure was successfully obtained from the blend of wool and black seed oil by using the electrospinning method.

Keywords: Nanofibers, electro-spinning method, black seed oil, wool oil, by-product, wound dressing

\section{GİRIŞ ve AMAÇ}

Nano boyuttaki malzemelerin geliştirilmesi sağlık uygulamalarında daha iyi tedavi imkanları sağlamaktadır. Yara iyileşmesini hızlandıran nano teknolojik malzemelerin günümüzde kullanılan birçok malzemenin yerine kullanılacağ1 düşünülmektedir. Nanolif elde etme tekniği olan elektro eğirme yöntemi, elektriksel ve hidrodinamik kuvvetlerin etkisinde malzemelere şekil verme işlemi olarak bilinmektedir. Elektro çekim tekniği nano boyutlarda liflerin eldesinde kullanılan basit, kurulumu maliyeti düşük, kolay ve hızlı, çok değişik polimerlerin işlenmesine elverişli, ticari üretime uygun bir tekniktir. S1v1 ve polimerin elektriksel olarak yüklenmesi bir toplayıcı üzerinde dağınık halde nanoliflerin toplanması temeline dayanan elektro çekim tekniği bilinen en yeni ve en kullanışlı nanolif elde etme yöntemidir. Literatürde çokça uygulama örneği vardır ve ticari üretim olanakları sunan bir üretim hattına dönüşmüştür. Elektro eğirme işlemini etkileyen birçok değişken vardır. Bu değişkenler çözeltiye ait, işleme ait ve çevresel değişkenler olarak ayrılır. Çözeltiye ait parametreler; viskozite, iletkenlik, yüzey gerilimi, çözeltinin konsantrasyonu, moleküler ağırlıklarıdır. İşleme ait değişkenler voltaj, besleme oranı, besleme hızı, düze ve toplayıcı arasındaki mesafe şeklindedir. Çevresel değişkenler ise çevre sıcaklığı ve nem miktarıdır. $\mathrm{Bu}$ çalışma kapsamında, elektro eğirme tekniği ile yün yağı ve çörek otu yağının kullanıldığı nanolif elde etme işleminde farklı konsantrasyonlarda kullanılan malzemelerin üretilen üründe gösterdiği değişimlerin incelenmesi ve değerlendirilmesi amaçlanmıştır. Atık halde bulunan yün yağının kullanılması önemli bir geri dönüşüm uygulamasıdır. Geri dönüşümlü katma değeri yüksek ürün tasarımına iyi bir örnek olacağı düşünülmektedir.

\subsection{Elektro Çekim Tekniği ile Nanolif Üretimi}

Elektro çekim yöntemi temel olarak, belirli konsantrasyonlarda hazırlanan polimer çözeltisine düşük akış hızları altında, kV mertebesinde bir elektrik kuvveti uygulayarak polimer çözeltinin nano boyutlu liflere dönüştürülmesini kapsamaktadır. Elektro çekim cihazı temel olarak 3 bölümden oluşmaktadır. İlk bölüm besleme bölümüdür. $\mathrm{Bu}$ bölümde pompa, enjektör, besleme kablosu ve nozzle bulunmaktadır. İkinci bölümde $\mathrm{kV}$ mertebesinde bir elektrik kuvveti sağlayacağımız güç kaynağı bulunmaktadır. Üçüncü bölümde ise nanolifleri üzerinde toplayacak belirli hızlarda dönen topraklanmış silindir ya da sabit olan bir topraklanmış plaka toplayıcı mekanizması vardır. Şekil 2'de elektro çekim cihazının temel bölümleri görülmektedir.

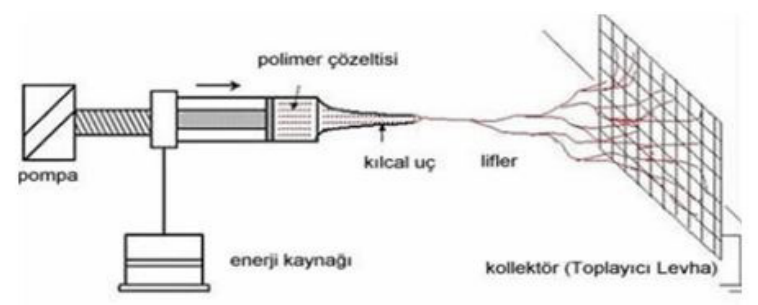

Şekil 1. Elektro çekim metodu şematik gösterimi

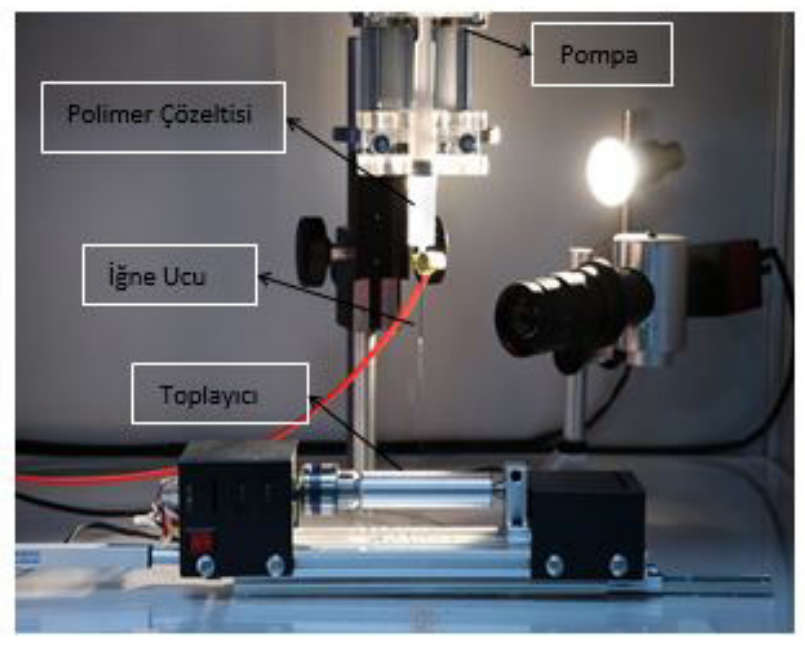

Şekil 2. Elektro çekim cihazı temel kısımları

Belirli hızlarda enjektörden gelen polimer çözeltisi adezyon kuvveti yardımıyla nozzle ucunda bir kürecik meydana getirir. Uygulanan gerilim bu küreciğin koni (Taylor Konisi) şeklini almasını sağlar ve gerilim polimer çözeltisinin yüzey gerilimini ve visko-elastik kuvveti eşiğini aştığı zaman polimer çözeltisinin oluşturduğu küreciklerden toplayıcıya doğru Şekil 1'de görüldüğü gibi jet akışı oluşumu başlar. [1]

İndüklenen polimer çözeltisi toplayıcı plakaya doğru incelerek uzar ve ayrışır. Bu işlem polimer çözeltisi bitene kadar ya da istenilen miktara kadar devam eder ve nano yapı, toplayııı plaka üzerinde birikerek nanolif elde edilir.

\subsection{Elektro Çekim Yönteminin Tıbbi Tekstilde Kullanımı}

Elektro çekim yöntemi ile elde edilen nanoliflerin kullanım alanı oldukça geniştir. Bunlara örnek olarak; kompozitler, filtrasyon uygulamaları, tıbbi uygulamalar, uzay uygulamaları, savunma uygulamaları, elektriksel ve optik 
uygulamalar, tarım uygulamaları ve diğer uygulamalar yer almaktadır.

Tekstil teknolojisi ve tıp bilimlerinin birleşimi, medikal tekstil denilen yeni bir alana yol ortaya çıkarmıştır.

- Tibbi tekstiller aynı zamanda 'Sağlık Tekstilleri' olarak da bilinir.

- Tibbi tekstiller tekstil pazarında en hızlı büyüyen sektörlerden biridir.

- Büyümenin boyutu hem tekstil teknolojisindeki hem de tıbbi prosedürlerdeki sürekli iyileştirmeler ve yeniliklerden kaynaklanmaktadır.

- Özel ihtiyaçları karşılamak üzere tasarlanan tekstil malzemeleri ve ürünleri; esneklik ve bazen nem ve hava geçirgenliği kombinasyonunun gerekli olduğu herhangi bir tıbbi ve cerrahi uygulama için uygundur.

- Kullanılan malzemeler arasında normal ve özel biyolojik olarak çözünebilen iplikler, monofilament ve multifilament iplikler, dokuma, örme ve nonwoven kumaşlar ve kompozit yapılar bulunur. [2]

Tablo 1'de, elektro çekim yönteminde farklı polimer maddelerin kullanılması ile elde edilen ürünler verilmektedir.

Tablo 1 Elektro çekimde kullanılan polimerler ve uygulamaları

\begin{tabular}{|l|l|}
\hline Polimerler & Uygulamaları \\
\hline Poly (glycolide) (PGA) & Nonwoven doku iskeleleri \\
\hline Poly (lactik-coglycolid)(PLGA) & $\begin{array}{l}\text { Biyomedikal uygulamalar, yara iyi- } \\
\text { leştirici }\end{array}$ \\
\hline Poly (kaprolaktone) (PCL) & Kemik doku mühendisliği \\
\hline Poly (laktik) (PLLA) & 3D hücre katmanı \\
\hline Poliüretan (PU) & $\begin{array}{l}\text { Nonwoven yara iyileştirici doku } \\
\text { şablonu }\end{array}$ \\
\hline Poli (etilen-covinil alkol) (PEVA) & $\begin{array}{l}\text { Nonwoven doku mühendisliği iske- } \\
\text { lesi }\end{array}$ \\
\hline Polistren (PS) & Cilt doku mühendisliği \\
\hline Sindiyotaktik 1,2 polibütadiyen & Doku mühendisliği uygulamaları \\
\hline Fibrinojen & Yara İyileştirici \\
\hline $\begin{array}{l}\text { Poly (vinil alkol) /selüloz asetat } \\
\text { (PVA/CA) }\end{array}$ & Biyomateryaller \\
\hline Selülöz Asetat & Emici membranlar/keçeler \\
\hline Poly (vinil alkol) & Yara örtüleri \\
\hline İpek fibroin,ipek/PEO & Doku İskelesi \\
\hline İpek & Biyomedikal Uygulamalar \\
\hline İpek fibroin & Yara iyileştirmek için doku iskelesi \\
\hline İpek/Kitosan & Yara örtüleri \\
\hline Kitosan/PEO & Doku iskelesi, yara iyileştirici \\
\hline Jelatin & Yara iyileştirmek için doku iskeleleri \\
\hline Hyaluronik asit (HA) & Medikal implant \\
\hline Selüloz & Membran \\
\hline Jelatin/Polianilin & Doku mühendisliği doku iskeleleri \\
\hline Kollajen/Kitosan & Biyomateryaller \\
\hline
\end{tabular}

\subsection{Tıbbi Uygulamalarda Kullanılan Tekstil Malzemeleri İçin Gereksinimler}

- Biyo-uyumlu ve steril olmalıdır.

- Anti alerjik ve anti bakteriyel olmalıdır.

- Alkalilere, asitlere ve mikro organizmalara karşı iyi dirençli olmalıdır.

- İyi boyutsal kararlılık ve esneklik sahip olmalıdır.

- Kirlenmeye karşı dirençli veya kir içermez olmalıdır.

- İyi bir sıvı Emiciliğe / İticiliğe ve hava geçirgenliğine sahip olmalıdır.

- Elyaf rengi beyaz olmalidır.

- Biyo bozunur ve Çevre dostu olmalıdır. [3]

\subsection{Yaralar ve İyileşme Süreci}

Yaralar çeşitli dış etkiler sonucunda vücut yapısında oluşan açılmalardır. Vücut yapısındaki hasarlanan dokunun tekrar onarılması yaranın iyileşme süreci olarak ifade edilir. Yaraların iyileşme süreçleri;

- İnflemasyon Fazı / 4 Gün

- Proliferasyon Faz1 / Ay

- Olgunlaşma Fazı / Birkaç yıl

Olmak üzere 3 aşamada gerçekleşir.

Yaraya uygun yara örtüsünün seçimi ve kullanımı yara iyileşmesinde oldukça önemlidir. Yara örtüleri yaraya uygulandıktan sonra yaraya herhangi bir ilaç uygulanmasına, yaranın atmosfer ile temasının kesilmesine, yaranın absorblanmasına imkân sağlar. Kullanıma uygun bir yara örtüsü;

- Yaranın iyileşme hızını artırmalı

- Yaradaki oluşabilecek kokuyu engellemeli

- Ağriyı azaltmalı

- Ciltte hasara neden olmamalı

- Ekonomik olarak uygun olmalıdır [4]

Yara örtüleri; yaralı bölgenin mikrop ve enfeksiyondan korunmasını sağlayan, iyileşme sürecine yardımcı olan medikal yöntem tekstil ürünleridir. Çok eski çağlardan itibaren, iyi bir yara iyileşmesi ve yaranın enfeksiyon kapmasını önlemek için uygun malzemeler kullanılmaya çalışılmış ve buna yönelik malzemeler geliştirilmiştir. 250'den fazla çeşidi bulunan yara ve yanık örtülerinin kullanımıyla, yara dokusundaki fazla eksudanın emiliminin ve nemli bir ortam sağlanmasının iyileşme sürecine katkı sağladığı bildirilmiştir. [5] 


\section{MATERYAL}

Bu bölümde, yapılan çalışma boyunca kullanılan kimyasal ve uygulamayı destekleyici malzemelere yer verilmiştir.

\subsection{Yün Lifi}

Yün lifinin kullanımı eski Mısırlılara ve Çinlilere kadar uzanmaktadır. Günümüzde ise teknik alanlarda hala kullanılmakta sadece yün olarak ya da karışım olarak da tercih edilmektedir.

Pamuktan sonra en çok kullanılan doğal lif yündür. Sağladığı ileri konfor ve teknik özelliklerinin çeşitli tekstil teknolojileri ve bitim işlemleri ile birleşmesiyle de teknik kullanımı gün geçtikçe artmaktadır.

\subsubsection{Yün Liflerinin Yapısı}

Yün lifi protein yapıda olup keratinden meydana gelmektedir. Yapısında 20 çeşit aminoasit bulunmaktadır. Yün lifi helisel formda bulunan bir zincir yapısına sahiptir. Yün lifleri diğer lifler ile kıyaslandığ 1 zaman diğer sentetik ve doğal liflerden daha fazla moleküler arası çekime sahiptir.

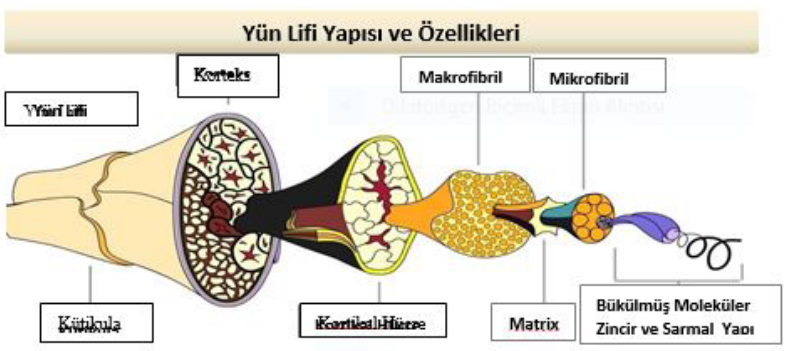

Şekil 3. Yün lifinin enine kesitinin incelenmesi [25]

Gelişmesini tamamlamış bir yün lifin enine kesiti mikroskop altında incelenecek olursa, bunun üç tabakadan meydana geldiği görülür. Bu tabakalar Şekil 3'de görüldüğü gibi dıştan içe doğru kütikula, korteks ve medulladır. Her tabaka kimyasal ve histolojik yapı bakımından birbirinden farkl1dır. Kütikula, lifin çevresini kaplayan pulcuk şeklindeki örtü hücrelerinden meydana gelen ince bir zardır.

Korteks tabakası yün liflerinin asıl maddesini teşkil eder. Merinos yünü gibi ince yünlerin içi tamamen bu tabaka ile doludur. Lifler tüm fiziksel ve kimyasal özelliklerini bu tabakadan alırlar. Bu tabakanın ilk bakışta iğ şeklinde uzunca, az veya çok bükülmüş ve boynuzlaşmış hücreler içerdiği görülür. Bu hücrelerin yapı taşları amino asitlerdir. Amino asitler, polipeptit halkalar halinde birleşerek makro molekülleri oluştururlar. Aslında bunlar birleşirken önce protofibriller ve bunlardan da mikrofibriller meydana gelir. En son da mikro fibriller birleşerek makro fibrilleri oluştururlar.
Medulla ise kaba liflerin orta kısımlarını dolduran kısımdır. Medulla içeren liflere daha çok yerli koyunlarımız gibi primitif koyunların yapağılarında (yünün üzerinde bulunan yün yağı, ter maddeleri ve deri döküntüleri) rastlanır. Bu tür lifler kaba ve kalın oldukları gibi, Medulla korteks tabakasının büyük kısmını işgal ettiğinden iyi boya almazlar. Tablo 2'de yün lifinde bulunan maddeler gösterilmiştir.

Tablo 2. Yün lifinde bulunan maddeler

\begin{tabular}{|c|c|c|}
\hline Element & Yün Lifi & Örtü Hücreleri \\
\hline Kükürt & 3,5 & 4,83 \\
\hline Sistin & 12,2 & 18,10 \\
\hline Azot & 16,67 & 13,53 \\
\hline Arginin & 8,60 & 4,30 \\
\hline Tyrozine & 6,10 & 3,00 \\
\hline Serine & 9,50 & 9,90 \\
\hline Etil Gruplar & - & 4,00 \\
\hline Kül & 0,20 & 4,10 \\
\hline Lipit Maddeler & - & 2,70 \\
\hline
\end{tabular}

Kükürdün değişik oranlarda bulunması ve sistin bağının daha kuvvetli olması, örtü hücrelerinin alkalilere karşı daha dayanıklı olmasını sağlar. Bu nedenle sodyum sülfat korteks tabakasını daha çok etkiler. Ayrıca örtü hücreleri, enzimlerin parçalayıcı etkilerinden daha az zarar görürler. [6]

\subsubsection{Yün Liflerinin Genel Özellikleri}

- Antimikrobiyal Özelliği

- Güç Tutuşurluk Özelliği

- Hidrokarbonların Absorbsiyonu ve Filtrasyonu Özelliği

\subsubsection{Yün Yağı (Lanolin-yün vaksı)}

Lanolin, koyun yünü üzerinde bulunan kokulu soluk sarı doğal yağdır. Yün işlemede atık ürün olarak yün yağı, yün mumu ya da lanolin olarak da bilinir. Bu yağ doğal bir su iticidir. Temel olarak işlevi ise koyunları su geçirmez hale getirmektir. Lanolin ayrıca koyun derisini enfeksiyondan koruyan mantar önleyici ve anti bakteriyel özelliklere sahiptir. Hayvanın yağ bezlerinden türetilen lanolin \%25-30 su kar1şımıdır. Yün yağı, kolesterol ve 18 ila 26 karbon atomu içeren 'yağl1' asitlerden türetilen esterler dahil olmak üzere birçok farklı kimyasal bileşiğin bir karışımıdır.

Lanolin ilaç ve kozmetik endüstrilerinde yaygın olarak kullanılmaktadır. Lanolin içindeki yağlar kimyasal bileşimde insan derisi tarafından salgılanan yağlara benzer. Dahası, cilt tarafindan kolayca emilen, yumuşatan ve cildin kurumasını ve çatlamasını önleyen bir maddedir. Her ne 
kadar lanolin bir yağ olarak adlandırılsa da oda sıcaklığında katı haldedir. Yaklaşık 38-42 ${ }^{\circ} \mathrm{C}\left(100-107^{\circ} \mathrm{F}\right)$ arasındaki bir sıcaklıkta erir. Su ile çözülmeyen bir yapıdadır, lanolini çözmek için kloroform ve eter kullanılmaktadır. [7]

\subsubsection{Yün Yağının Kullanım Alanı}

- $\quad$ Mükemmel bir su itici olduğundan, lanolin korozyon önleyici (paslanma sürecini yavaşlatan bir ajan) olarak otomotiv sektöründe kullanılmaktadır.

- Yedek otomobil parçaları bazen uzun süreli depolamaya alındıklarında lanolin ile kaplanır.

- Kimyasal olarak insan derisi tarafindan doğal olarak üretilen birçok yağa benzediğinden, ilaç endüstrisinde yaygın olarak kullanılmaktadır.

- Lanolin, ilaçları deri altından (yani derinin hemen altında) vermek için bir 'taşıyıcı' olarak kullanılmıştır.

- Lanolin deri kaplama ve koruyucu olarak da kullanilabilir.

- Bazı verniklerde ve boyalarda lanolin kullanılmaktadir.

- Güneş yanığını tedavi etmek ve önlemek için kullanılmaktadır.

- Kesiklerin, yaraların ve sıyrıkların iyileşmesini hızlandırmak için kullanılmaktadır.

- Gemi bağlantı elemanlarında korozyon önleyici olarak kullanılır.

- Ayakkabı cilası olarak kullanılmaktadır.

- Lanolin yağı insan vücudu ile biyo uyumlu bir yapıda olduğu için günümüzde genellikle tıbbi tekstil uygulamalarında tercih edilmektedir. [7]

\section{2. Çörek Otu}

Nigella sativa 20 ile $30 \mathrm{~cm}$ arasında uzama ile çiçek oluşumu gösteren bir türdür. Çörek otu düz, doğrusal bir yaprak yapısına sahiptir. Çörek otunun narin yapıdaki çiçekleri 5 ile 10 arasında değişim gösteren taç yapraklardan meydana gelmektedir.

Çiçeklerinin rengi genelde sarı, pembe, beyaz, mor renklerindedir. Çörek otunun meyve kısmı büyük olup kapsül yapısındadır ve kapsüllerde çok sayıda tohum mevcuttur. [8] [9].Tohumların siyah renkte olanları yayvan ve huni bir şekildedir. [8]

Çörek otunun tohumları baharat ve halk arasında bazı hastalıkların tedavi biçimi olarak görülmektedir. Orta Doğu ve Uzak Doğu bölgelerinde halk arasında astım, bronşite öksürük, ateş, ağrı, bağırsak problemleri, diyabet vb. hastalikların tedavisinde uygulanmaktadır. [10]

Bunun dışında bazı gıda maddelerinde de süsleme ve lezzet verme amacıyla çörek otu tohumu kullanılmaktadır. Çörek otunun tohumunun besin değeri oldukça yüksek olup içerisinde birçok faydalı bileşen barındırmaktadır. Tablo 3'de gösterildiği gibi tohum yapısında doymuş ve doymamış olmak üzere yağlar, uçucu olan yağlar, karbonhidrat, protein, amino asit, lif, mineraller, folik asitler mevcuttur. [11]

Tablo 3. Nigella sativa tohumunun içeriği

\begin{tabular}{|c|c|}
\hline İÇERİK & $\%(\mathrm{w} / \mathrm{w})$ \\
\hline Yă̆ & $31-35.5$ \\
\hline Protein & $16-19.9$ \\
\hline Karbonhidrat & $33-34$ \\
\hline Lif & $4.5-6.5$ \\
\hline Saponin & 0.013 \\
\hline Nem & 5.7 \\
\hline Kül & $3.7-7$ \\
\hline
\end{tabular}

Çörek otu tohumunun yapısındaki yağ asitleri, linolenik asitler, oleik asitler, linoleik asit, araşidonik asit, palmitoleik asit, eikozadinoik asittir. Doymuş yağ asitleri ise palmitik asit, stearik asit, miristik asitlerdir [11].

Çörek otu tohumu yapısında belirli bir oranda mineralde bulundurmaktadır. Tohumun yapısında en çok potasyum bulunurken bunu takiben sirası ile kalsiyum, sodyum, demir mineralleri bulunur [12]. Çörek otu tohumunun barındırdığı vitamin ve mineral miktarları ölçüldüğünde, tohumlarının fazla miktarda tiamin, pridoksin ve niasin bulundurdukları gözlenmiştir.

Çörek otu tohumundan elde edilen yağın üretimi en çok Akdeniz ülkeleri tarafından yapılmaktadır. Nigella sativa tohumunun yağı soğuk pres ile yüksek basınç uygulanması sonucu elde edilmektedir. Bu hassas yapılan işlem esansiyel yağların üretimi için oldukça önemlidir. Çörek otu yağının aromatik bir kokusu ve kızılımsı sarı renkte bir rengi, acı bir tadi vardir. [13].

\subsection{Kullanılan Çözücüler}

\subsubsection{Diklorometan}

Diklorometan diğer adiyla metilen klorür $\mathrm{CH}_{2} \mathrm{CL}_{2}$ formüllü bir organik bileşiktir. İnhalasyon anestezik tesirleri bulunan dikolorometan yüksek konsantrasyonlarda ise narkotik bir tesir meydana getiren klorlu yapıdaki hidrokarbon bileşiğidir. Dikolorometan hafif bir kokuya, saydam bir görüntüye sahiptir. $\mathrm{Bu}$ özellikleri ile eter maddesine benzemektedir. Dikolorometan bileşiğinin uçucu özelliği oldukça 
fazladır. Şekil 4'de Diklorometan kimyasal açık formülü gösterilmiştir.

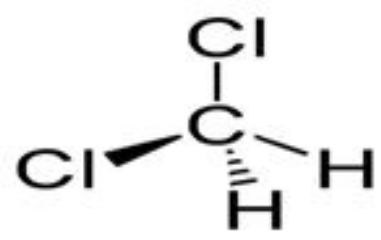

Şekil 4. Diklorometan kimyasal açık formülü

\subsubsection{Kullanım Alanı}

- Antibiyotik ve vitamin elde edilmesinde kristalizasyon çözücüsü olarak kullanılır.

- Aerosollerde çözücü, yanma engelleyici, buhar basıncını azaltıcı ve viskozite azaltıcı olarak kullanılır.

- Üretilen parçaların birbirine yapışmaması için ayırıcı olarak uygulanmaktadır.

- Metilen klorür endüstriyel üretimde çözücü amacıyla kullanılmaktadır.

- Piyasada genelde boya çıkarıcı olarak ve yağ çözmede kullanılır.

- Gıda üretiminde çay ve kahve gibi içeceklerin kafein oranlarını düşürmek için tüketilir.

- Poliüretan malzemeli köpüklere kabartıcı etki sağlaması için de kullanılır [14]. [15]

\subsubsection{Dimetilformamid}

Dimetilformamid diğer adıyla DMF organik bir bileşik olup su ve birçok organik madde ile karışım sağlayabilir. Şekil 5'de Dimetilformamid kimyasal açık formülü gösterilmiştir.

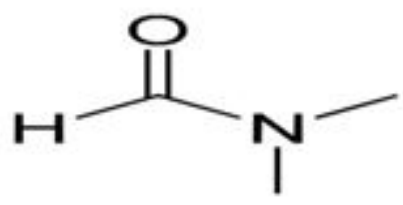

Şekil 5. Dimetilformamid kimyasal açık formülü

\subsubsection{Dimetilformamid'in Özellikleri}

- Hafif amonyak kokuludur.

- Düşük oranda uçuculuk özelliğine sahiptir.
- Dimetilformamid buharı yanıcı bir özellik gösterir.

- Su ile her oranda karışım sağlayabilir.

- Eter, alkol, keton ve aromatik hidrokarbon bileşiklerinde erime gösterir.

- Asit ve bazik çözelti haricinde kararlılık gösterirler.

- Alifatik hidrokarbon maddelerde az miktarda çözünür.

\subsubsection{Kullanım Alanı}

- Polimer, reçine çözmede kullanılır.

- Kimyasal tepkimelerde katalizör olarak

- Elektrolit çözmede

- Herhangi bir üretimde hammadde olarak

- Kristalizasyonlarda çözücü etki sağlamak için

- İlaç sanayisinde ekstraksiyonda, tepkimelerde ve banyonun kristallendirilmesinde kullanılır. [16] [17]

\subsection{Kullanılan Polimer}

\subsubsection{PLA Polimeri}

Tekrar eden birimleri laktik asit 'ten oluşan PLA polimeri, alifatik polyester grubuna girmektedir. Mısır, şeker kamış1, buğday ve nişasta gibi doğal bitkisel ürünlerden elde edilen biyo çözünür yani doğada çözünebilen bir polimerdir.

\subsubsection{PLA Polimeri Eldesi}

PLA polimerini oluşturan laktik asit monomeri, karbonhidrat fermantasyonu yoluyla ya da kimyasal sentez yoluyla üretilebilmektedir. Günümüzde genellikle fermantasyon yoluyla elde edilmektedir.

\subsubsection{PLA Polimerinin Tercih Edilmesi ve Tıbbi Tekstilde Kullanımı}

Laktik asit her insanın ve bazı hayvanların vücudunda oluşan organik bir bileşiktir. Genellikle kas ve kanda bulunmaktadır. Laktik asit insanda ya da hayvanda kas dokularıyla ilişkili olduğu için vücudun kendi metabolizması içerisinde çözünebilecek bir maddedir.

Bu çözülme sırası; laktik asit ilk önce pürik aside çevrilir, karbondioksit ve su sağlamak için trikarboksilik asit döngüsüne girmektedir. Bunun sonucunda laktik asidin çözünmesiyle organlarda herhangi bir kalıntıya rastlanmaz. Laktik asit böyle bir döngüyü tamamladığından dolayı biyo bozunur bir madde olarak adlandırılmaktadır.

PLA polimeri daha evvelden de bahsedildiği gibi laktik asit monomerinin polimerleşmesi ile meydana gelmektedir. 
PLA polimerinin en çok tıbbi tekstilde kullanımı tercih edilmektedir. Bunun sebebi elbette ki polimerin yukar1daki bölümde değinilen kimyasal ve fiziksel özelliklerinden kaynaklıdır. Tıbbi tekstilde ise en çok cerrahi dikiş ipliği kullanımında tercih edilmektedir. Bunun sebebi ise PLA polimerinin insan vücuduna uyumlu yani biyo bozunur özelliği göstermesindendir.

PLLA polimeri ise çok yavaş çözündüğü için cerrahi dikiş iplikleri kullanımında tercih edilmemektedir. Fakat uzun süre mukavemet gerektiren uygulamalarda ise tercih edilmektedir. Örneğin bu uygulamalar; bağ doku, tendon yap1ları, vasküler ve ürolojik cerrahi için olan stent uygulamalarıdır. [18]

\section{5.Çözeltide Kullanılan Dolgu Maddesi}

\subsubsection{Tween-80}

Kimya sanayisinde Polisorbat 80 olarak da adlandirılmaktadır. Polietoksillenmiş sorbitan ve oleik asitten türetilmiştir. Genellikle gıdalarda ve kozmetik ürünlerinde kullanılan noniyonik bir yüzey aktif maddedir. Bu madde suda ve alkolde çözülür, yağda çözülmez. Genellikle oda spreyleri ve parfümlerde uçucu yağlar için viskozite değiştirme ve dağıtma maddesi olarak kullanılan emülsiyonlaştırıcı bir maddedir. [19]

\subsection{Elektro Çekim Metodunda Kullanılan Cihazlar}

\subsubsection{Manyetik Karıştırııı}

Fiziksel homojenliğin sağlanması için ISOLAB manyetik karıştırıcı kullanıldı. Marmara Üniversitesi Tekstil Mühendisliği Bölümü, Malzeme laboratuvarında bulunan Şekil 6'da görülen manyetik karıştırıcıda 3 saat karıştırılarak hazırlandi.

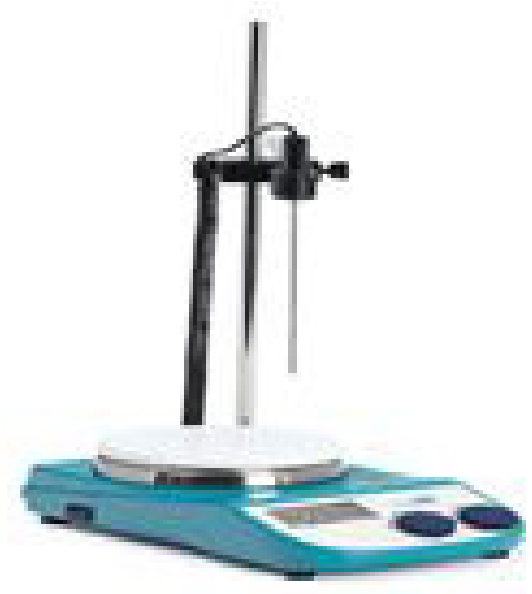

Şekil 6. "ISOLAB" markalı manyetik karıştırıcı

\subsubsection{Hassas Terazi}

Beş farklı konsantrasyonlarda çözelti hazırlamak için, Şekil 7'de gösterilmiş olan $0.10 \mathrm{~g}$ hassasiyetli terazi kullanildi.

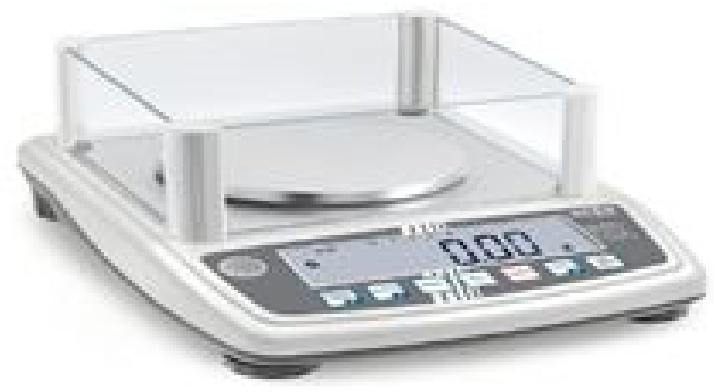

Şekil 7. "Ker PFB” markalı hassas terazi

\subsubsection{Viskozite Test Cihazı}

Farklı konsantrasyonlarda hazırlanan PLA - Yün Çörek Otu Yağı çözeltisinin viskoziteleri BROOKFIELD DV-E VISCOMETER markalı viskoz metre cihazı ile ölçüldü.

\section{METOT}

\section{1. Çözelti Hazırlama}

Tablo 4'de farklı konsantrasyonlarda hazırlanmış olan 5 farklı uygulama için ayrı ayrı çözelti hazırlanmış olduğu gösterilmektedir. Bu 5 uygulamada kullanılan PLA polimeri 15 ml'lik çözeltinin \%8' i kadar kullanılmıştır. Değişen konsantrasyon takviye çözeltisi olan yün yağı ve çörek otu yağı çözeltisinin $15 \mathrm{ml}$ 'lik polimer çözeltisine ilavesi ile elde edilmiştir.

Tablo 4. Yapılan Uygulamalar

\begin{tabular}{|l|c|}
\hline Uygulamalar & Miktar (\%) \\
\hline 1-) PLA/Yün Yağ1/Çörek Otu Yağ1 & $99 / 0.5 / 0.5$ \\
\hline 2-) PLA/Yün Yağ1/Çörek Otu Yağ1 & $98 / 1 / 1$ \\
\hline 3-) PLA/Yün Yağ1/Çörek Otu Yağ1 & $96 / 2 / 2$ \\
\hline 4-) PLA/Yün Yağ1/Çörek Otu Yağ1 & $90 / 5 / 5$ \\
\hline 5-) PLA/Yün Yağ1/Çörek Otu Yağ1 & $80 / 10 / 10$ \\
\hline
\end{tabular}

\subsection{Polimer Çözeltisinin Hazırlanması}

Kullanılan polimer (PLA) 15ml'lik çözelti içerisinde \%8 konsantrasyonda 1,2 gram kullanılmıştır. Polimeri çözebilmek için 4/1 oranında $12 \mathrm{ml}$ Diklorometan (DCM) ve $3 \mathrm{ml}$ N, N-Dimetilformamid (DMF) çözücüsü kullanılmıştır.

İzlenilen proses;

- PLA polimeri hassas terazide beher içerisinde 1,2 gram tartılir. 
- Beher içerisine 12 ml DCM, 3 ml DMF çözücüsü pipet yardımı ile ilave edilir.

- Beherin içerisine 1 adet balık koyulur.

- Çözücünün buharlaşmaması için beherin ağzı alüminyum folyo ile kaplanır.

- $\quad$ İçerisinde çözelti bulunan beher manyetik karıştırıcıda 3 saat boyunca 500 rpm hız ile karıştırılır.

\subsection{Takviye Çözeltisinin Hazırlanması}

\%1 Takviye Uygulaması İçin;

Bir diğer çözelti olan takviye çözeltisi için 50/50 oranında karışım yapılmaktadır. \%1'lik çözelti için 0,5gram yün yağı, 0,5 gram çörek otu yağı kullanılmıştır. İstenilen miktarda hassas terazi üzerinde tartılan takviye maddelerini çözebilmek için DCM çözeltisi kullanılmaktadır. 1 gram takviye maddesi için $10 \mathrm{ml}$ DCM kullanılmıştır.

Çözeltiyi homojen bir şekilde çözebilmek için yukarıda anlatılan işlem akışında Şekil 8'de gösterilen manyetik karıştırıcı üzerinde 3 saat boyunca 500 RPM hızda karıştırılmıştır.

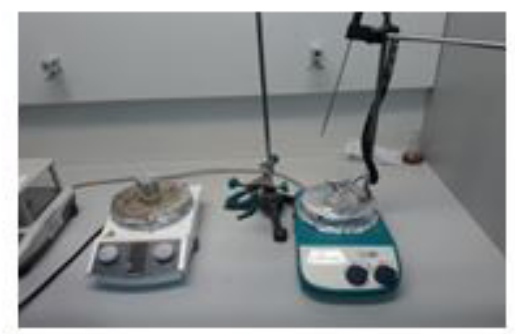

Şekil 8 Çözeltiler ayrı beherler içerisinde çözünmekte

2 çözeltide homojen bir şekilde karıştırıldıktan sonra uygulamada kullanılacak konsantrasyonda çözelti elde edebilmek için 2 çözeltiden istenilen miktarda Şekil 9'da gösterilen Mikro pipet yardımıyla çözelti çekilmektedir.

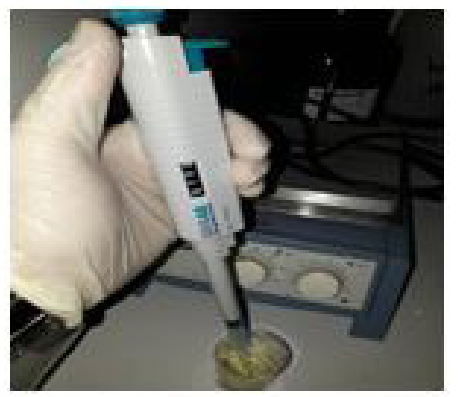

Şekil 9. Mikro pipet ile çözücü çekimi
$15 \mathrm{ml}$ çözelti oluşturmak için; \%99 oranında 14,85 ml PLA ve \%1 oranında $0,15 \mathrm{ml}$ yün çörek otu yağı karışımı kullanılmıştır.

\subsection{Diğer Çözeltilerin Hazırlanması ve Testlerin Yapılması}

Diğer çözeltilerin proses aşamaları aynıdır. Konsantrasyonu etkileyen çözeltilerden çekilen miktardır.

- $15 \mathrm{ml}$ 'ye tamamlanmış çözeltiye çözeltinin \%3’ü konsantrasyonunda yani 0,5 gram kadar Tween- 80 maddesi eklenir. Tween- 80 maddesi çözeltinin viskozitesini stabil hale getirmek için kullanılmaktadır.

- Çözelti yarım saat kadar 500 RPM hızda karıştırılarak homojen hale getirilir.

- Çözelti bu aşamadan sonra viskozite ve iletkenlik testi için hazır hale gelmektedir.

\subsubsection{Viskozite Testi}

Farklı konsantrasyonlarda hazırlanan PLA-Yün Çörek Otu Yağı çözeltisinin viskoziteleri Şekil 10'da görülen BROOKFIELD DV-E VISCOMETER markalı cihaz ile ölçüldü.

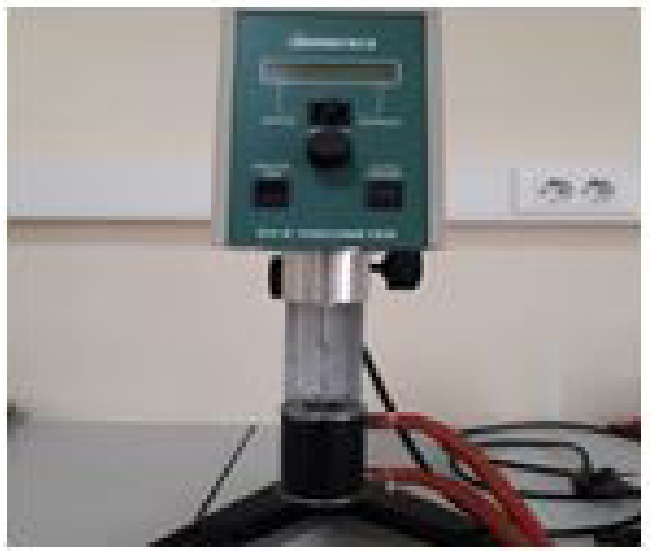

Şekil 10. Viskozite Test Cihazı

Viskozite testi aşamaları aşağıda maddeler halinde sıralanmıştır;

Ölçümü yapılacak çözeltinin viskoz metre cihazının haznesinin yarısını dolduracak kadar ilave edilir.

1. Viskoz metre cihazında kullanılacak uygun spinneret başlığı seçilir.

2. Çözeltinin ilave edildiği hazne cihaza yerleştirilir.

3. Spinneret başlığının dönüş hızı 100 RPM seçilir. 
4. Cihaz çalıștırılır ve ekranda okunan değer not alınır.

\subsubsection{Illetkenlik Testi}

Farklı konsantrasyonlarda hazırlanan PLA - Yün Çörek Otu Yağı çözeltilerinin iletkenlikleri Şekil 11'de görülen COND 3110 markalı iletkenlik ölçüm cihazı ile ölçüldü

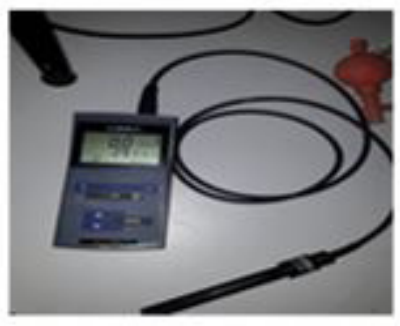

Şekil 11. İletkenlik test cihazı

İletkenlik testi proses aşamaları aşağıda maddeler halinde sıralanmıştır;

1. Cihazın probu temizlenmiş bir şekilde cihaza takılmalidir.

2. Çözelti $10 \mathrm{ml}$ 'lik şırınga içerisinde $3-4 \mathrm{ml}$ arasında konulur.

3. Prob, şırınganın içine sokulur ve 15 saniye beklenilir.

4. Cihazın ekranı üzerinde görünen değer not alınır.

Tablo 5'de konsantrasyonlar, çözeltilerde çekilen miktarlar, viskozite test sonuçları, iletkenlik test sonuçları verilmiştir;

Tablo 5. Uygulamaların çözelti oranları, üretim miktarları, viskozite değerleri ve iletkenlik değerleri

\begin{tabular}{|l|c|c|c|c|}
\hline Uygulamalar & $\begin{array}{c}\text { Miktar } \\
(\%)\end{array}$ & $\begin{array}{c}\text { Çekilen Mik- } \\
\operatorname{tar}(\mathrm{ml})\end{array}$ & $\begin{array}{c}\text { Visko- } \\
\text { zite Değeri } \\
(\mathrm{CP})\end{array}$ & $\begin{array}{c}\text { İletkenlik } \\
\text { Değeri } \\
(\mu \mathrm{S} / \mathrm{cm})\end{array}$ \\
\hline $\begin{array}{l}\text { 1-) PLA/Yün Yağ1/ } \\
\text { Çörek Otu Yağ1 }\end{array}$ & $99 / 1$ & $14,85 / 0,15$ & 31 & 4 \\
\hline $\begin{array}{l}\text { 2-) PLA/Yün Yağ1/ } \\
\text { Cörek Otu Yağ1 }\end{array}$ & $98 / 2$ & $14,70 / 0,30$ & 43 & 4,2 \\
\hline $\begin{array}{l}\text { 3-) PLA/Yün Yağ1/ } \\
\text { Çörek Otu Yağ1 }\end{array}$ & $96 / 4$ & $14,4 / 0,6$ & 39,9 & 4,4 \\
\hline $\begin{array}{l}\text { 4-) PLA/Yün Yağ1/ } \\
\text { Çörek Otu Yağ1 }\end{array}$ & $90 / 10$ & $13,5 / 1,5$ & 57,5 & 4,5 \\
\hline $\begin{array}{l}\text { 5-) PLA/Yün Yağ1/ } \\
\text { Çörek Otu Yağ1 }\end{array}$ & $80 / 20$ & $12 / 3$ & 84 & 4,8 \\
\hline
\end{tabular}

\subsection{Elektro Çekim Cihazı ile Yara Örtüsü Eldesi}

Proses aşamaları maddeler halinde sıralanacak olursa;
1. Viskozite testinin yapıldığı şırınga içerisinde ki 3-4ml'lik çözelti 10 mm' ye tamamlanmaktadır.

2. Şırınga ucu ile kapatılan çözeltinin hava ile teması engellenir.

3. Şırınga makinenin besleme kısmına yerleştirilir.

4. Makinenin kıskaçları ile şırınga besleme kısmına sabitlenir.

5. Ağızlık ile Toplayıcı arasında ki mesafeyi ayarlamak amacıyla çelik aksam kullanılır. Uygulamada ağızlık ile toplayıcı arasındaki mesafe $12 \mathrm{~cm}$ 'dir.

6. Çelik aksamın ucuna ağızlık yerleştirilir. Ardından çelik aksam makineye yerleştirilir. Şekil 12'de gösterilmiştir.

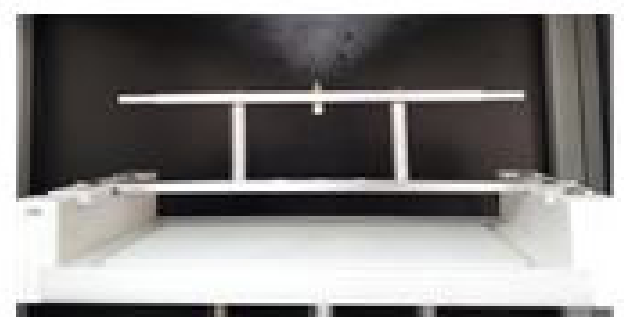

Şekil 12. Çelik aksam ve ortasındaki ağızlık

7. Şekil 13'de toplayıcı üzerine nanolif toplanması için yağlı kâğıt kullanılması gerektiği gösterilmiştir.

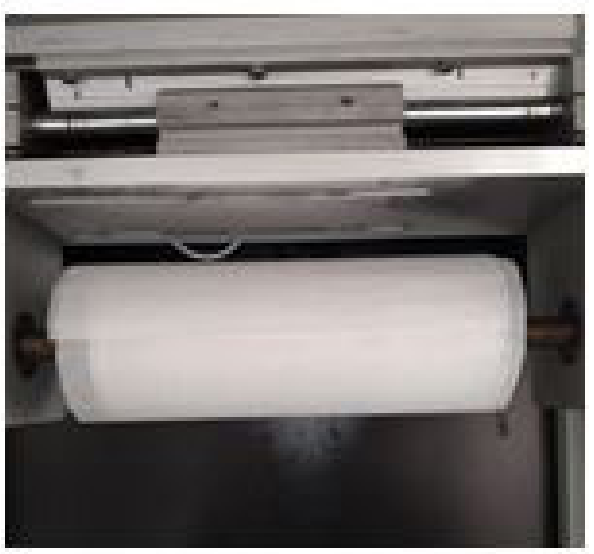

Şekil 13. Toplayıcı üzerine yerleştirilmiş yağlı kâğıt

Şırınganın ucuna çözeltinin sıdırmazlığını sağlamak için beyaz renkte sızdırmaz başılık takılmıştır. Ağızlık ile şırınga arasında çözelti akışının sağlanması için 2 mm 
çapında bir kablo ile bağlantı sağlanmıştır. Şekil 14'de bağlantı kablosu ve sızdırmaz başlık ifade edilmiştir.

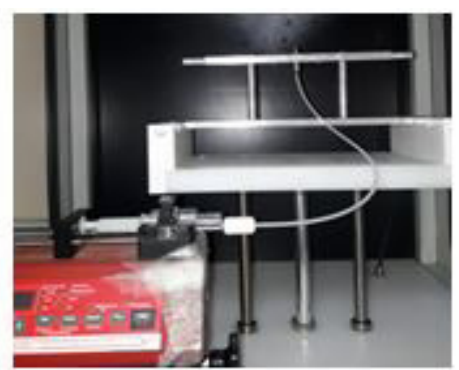

Şekil 14. Çözelti akışını sağlayan bağlantı kablosu

8. Besleme bölgesinde yer alan pompanın start düğmesine basılarak, çözelti ağızlığın ucuna gelene kadar basılı tutulur. Çözelti ağızlığın ucuna geldiğinde peçete yardımıyla ağızlıktaki fazla çözelti silinir.

9. Pompanın ayar kısmından çözeltinin akış hızı ayarlanır. Çözeltinin akış hızı mm/h olarak kullanılır.

10. Daha sonra makinenin kapağı kapatılır ve makinenin kontrol bölümünde ayar yapılır.

Makinenin gerekli ayarı yapıldıktan sonra üretime geçilir. Farklı konsantrasyonlarda yapılan uygulama için makine ayarı Tablo 6'da verilmektedir.

Tablo 6. Uygulamaların genel üretim bilgileri

\begin{tabular}{|l|c|c|c|c|c|c|}
\hline Uygulamalar & $\begin{array}{c}\text { Konsant- } \\
\text { rasyon } \\
(\%)\end{array}$ & $\begin{array}{c}\text { Voltaj } \\
(\mathrm{kV})\end{array}$ & $\begin{array}{c}\text { Ak1ş H1- } \\
\text { z1(m- } \\
\mathrm{m} / \mathrm{h})\end{array}$ & $\begin{array}{c}\text { S1caklık } \\
\left(\mathrm{C}^{\circ}\right)\end{array}$ & $\begin{array}{c}\text { RPM } \\
\text { (Top- } \\
\text { layı1c1 } \\
\text { Dönüş } \\
\text { Hız1 })\end{array}$ & $\begin{array}{c}\text { Mesafe } \\
(\mathrm{Cm})\end{array}$ \\
\hline $\begin{array}{l}\text { PLA/Yün } \\
\text { Yağ1/Çörek } \\
\text { Otu Yağ1 }\end{array}$ & $99 / 0.5 / 0.5$ & 32 & 1,6 & 22 & 100 & 12 \\
\hline $\begin{array}{l}\text { PLA/Yün } \\
\text { Yağ1/Çörek } \\
\text { Otu Yağ1 }\end{array}$ & $98 / 1 / 1$ & 31,5 & 1,7 & 22 & 100 & 12 \\
\hline $\begin{array}{l}\text { PLA/Yün } \\
\text { Yağ1/Çörek } \\
\text { Otu Yağ1 }\end{array}$ & $96 / 2 / 2$ & 31,8 & 1,7 & 22 & 100 & 12 \\
\hline $\begin{array}{l}\text { PLA/Yün } \\
\text { Yağ1/Çörek } \\
\text { Otu Yağ1 }\end{array}$ & $90 / 5 / 5$ & 31,8 & 1,7 & 22 & 100 & 12 \\
\hline $\begin{array}{l}\text { PLA/Yün } \\
\text { Yağ1/Çörek } \\
\text { Otu Yağ1 }\end{array}$ & $80 / 10 / 10$ & 32 & 1,8 & 22 & 100 & 12 \\
\hline
\end{tabular}

- Yukarıda ki tabloda yazılan ayarlamalar RPM ve mesafe standartlardan faydalanılarak elde edilen verilerdir.
- Voltaj ve akış hızı değerlerinin ise üretim esnasında deneyerek ve gözlemler sonucu en uygun akışın gerçekleşmesini sağlayan değerler tespit edilmiştir.

- Sicaklık değeri ise $22 \mathrm{C}^{\circ}$ de kontrol edilmiştir.

\section{Yara Örtüsü Üzerine Son Yıllarda Yapılan Çalışmalar}

\subsection{Yara Örtüsü Alanında Yapılan Çalışmaların Sebebi}

Son yıllarda, yara örtüsü alanında özellikle yurt dışında yapılan araştırmalar ve uygulamalar ön plana çıkmaktadır. Yapılan çalışmaların asıl amacı yarayı çeşitli bakteri, toz, sıvı vb. dış etkenlere karşı daha iyi koruyarak ve buna ek olarak yara örtüsünün gözenekli yapıda olması, insan vücuduna uyumlu bir polimer maddesinin kullanılması ile yara için optimum koşulların sağlanması ve yaranın iyileşme sürecinin hızlandırılması amaçlanır. Aşağıda son yıllarda yara örtüsü alanında en çok tercih edilen polimer maddeler ve yara örtüsüne etkileri hakkında bilgiler verilmiştir.

Tablo 7'de, farklı hammaddeler ile yapılan yara örtüsü uygulamalarının karakteristik özellikleri ve uygulama detayları verilmiştir [20];

Tablo 7. Farklı Yara Örtülerinin Uygulama Alanları ve Karakteristik Özellikleri

\begin{tabular}{|c|c|c|}
\hline $\begin{array}{l}\text { Yara Örtüsü } \\
\text { Tipi }\end{array}$ & Karakteristik Özelliği & $\begin{array}{l}\text { Uygulama ve } \\
\text { Detaylar }\end{array}$ \\
\hline $\begin{array}{l}\text { Hayvansal } \\
\text { Kaynaklı (Ka- } \\
\text { lojen vb.) } \\
\end{array}$ & $\begin{array}{l}\text { Gözenekli, hidrofilik özellikler, } \\
\text { yüksek emme kabiliyeti }\end{array}$ & $\begin{array}{l}\text { Akut yaralar, } \\
\text { geçmeyen ya- } \\
\text { ralar }\end{array}$ \\
\hline $\begin{array}{l}\text { Bitkisel Kö- } \\
\text { kenli (Pamuk, } \\
\text { viskoz vb.) }\end{array}$ & $\begin{array}{l}\text { Çoğunlukla selüloz, viskoz veya } \\
\text { her ikisinin bir karışımından oluş- } \\
\text { turulur, cilde oldukça yapışır, ço- } \\
\text { ğunlukla çift katmanlı, } 15-25 \text { g/g } \\
\text { adsorpsiyon kabiliyeti göstermek- } \\
\text { tedir. }\end{array}$ & $\begin{array}{l}\text { Yanık yaraları, } \\
\text { kronik yaralar } \\
\text { ve ülser yaraları }\end{array}$ \\
\hline $\begin{array}{l}\text { Sentetik Kö- } \\
\text { kenli (Poliüre- } \\
\text { tan, PCL, PLA } \\
\text { vb.) }\end{array}$ & $\begin{array}{l}\text { Yaklaş1k 200-300 gözenek /cm2 } \\
\text { gözenek dağılım1, yüksek mukave- } \\
\text { metli özellik gösterir. }\end{array}$ & Kuru yaralar \\
\hline Kitosan & $\begin{array}{l}\text { Yüksek drenaj özelliği, su itici yü- } \\
\text { zey ve yüksek hava geçirgenliği } \\
\text { sağlar. }\end{array}$ & Enfekte yaralar \\
\hline $\begin{array}{l}\text { Sodyum Al- } \\
\text { ginat }\end{array}$ & $\begin{array}{l}\text { Lifli ve çok emici yapıdadır. İkinci } \\
\text { bir kanamayı önleyici madde ge- } \\
\text { rektirmektedir. }\end{array}$ & $\begin{array}{l}\text { Islak ve kuru ya- } \\
\text { ralar }\end{array}$ \\
\hline Hidrojeller & \begin{tabular}{|l|} 
Şeffaf, nemli bir yara ortamını ko- \\
rur, ölü dokunun uzaklaştırılma- \\
sını kolaylaştırır ve düşük ila orta \\
eksüdalı yaralar için uygundur
\end{tabular} & $\begin{array}{l}\text { Yanıklarda, cer- } \\
\text { rahi yaralarda, } \\
\text { cilt su toplama- } \\
\text { larında ve bası } \\
\text { yaralarında ve } \\
\text { iltihaplı yaralar }\end{array}$ \\
\hline
\end{tabular}




\begin{tabular}{|l|l|l|}
\hline Hidrokolloid & $\begin{array}{l}\text { T1kayıcıdır, bakteri büyümesini } \\
\text { engelleyen, düşük drenajı olan ya- } \\
\text { ralar için uygundur ve mükemmel } \\
\text { yapışma özelliği gösterir. }\end{array}$ & $\begin{array}{l}\text { Genellikle kü- } \\
\text { çük yanıklar, } \\
\text { şok yaralanma- } \\
\text { ları ve çürükler } \\
\text { gibi yüzey ül- } \\
\text { serleri, 1slak ve } \\
\text { kuru yaralar }\end{array}$ \\
\hline $\begin{array}{l}\text { İlaç Salınım- } \\
\text { lı(Antibiyotik, } \\
\text { vitamin vb.) }\end{array}$ & $\begin{array}{l}\text { Daha kısa kullanım süresi, yara } \\
\text { enfeksiyonlarını önler, nekrotik } \\
\text { dokuların çıarılmasını kolaylaş- } \\
\text { tırır ve doku yenilenmesini des- } \\
\text { tekler. }\end{array}$ & $\begin{array}{l}\text { Enfekte-iltihaplı } \\
\text { yaralar }\end{array}$ \\
\hline
\end{tabular}

\subsection{Kitosan Polimerinin Yara Örtüsü Uygulamalarında Kullanımı}

Kitosan, antimikrobiyal aktivitesi ve iyileştirme özelliği nedeniyle biyomedikal uygulamalarda sıklıkla kullanılan bir doğal polimerdir. Ayrıca drenajı teşvik eder, yani su itici özellik gösterir. Yara iyileşme sürecinde gerekli olan gaz değişimini destekler, bu sayede yaranın iyileşme sürecini hızlandırır. Tablo 6' da görüldüğü üzere drenaj ve hava geçirgenliği özelliğinden dolayı enfekte yaralar üzerinde tercih edilmektedir, Aynı zamanda birçok polimer ile ortak çözelti de kullanılabilmektedir. [21]

\subsection{PCL Polimerinin Yara Örtüsü Uygulamalarında Kullanımı}

PCL polimerinin yara örtüsü alanında kullanımı son yıllarda araştırmacılar tarafından ele alınmıştır. PCL, yarı kristalin yapıya sahip biyobozunur ve biyouyumlu bir polimer özelliği gösterir. PCL kullanılarak elde edilen elektro eğrilmiş yüzeyler gözenekli yapıya sahip elastik morfoloji sayesinde gaz değişimine olanak sağlamakta ve yara bölgesini absorblamaktadır. Fakat PCL polimerinin yara örtüsü alanında kullanımını kısıtlayacak bazı dezavantajları vardır. Örneğin, PCL polimerinden elde edilen yara örtüsü, yara bölgesine kuvvetli bir şekilde tutunma davranışını göstermektedir. Bu durumda tamir olan yeni deri dokusunun zarar görmesine ve yara iyileşme sürecinin uzamasına neden olmaktadır. Ayrıca Tablo 6'da görüldüğü gibi PCL ve diğer sentetik kökenli polimerler kuru yara uygulamalarında kullanılır. Fakat kuvvetli tutucu özelliği gösterdiği için dirsek ve diz kapağ 1 gibi oynar bölgeler üzerinde kullanılması tercih edilmemektedir. [22]

\subsection{Poliüretan Polimerinin Yara Örtüsü Uygulamalarında Kullanımı}

$\mathrm{Bu}$ yara örtüleri çoğunlukla kuru yaralarda kullanılmakta olup, nemli bir yara ortamı oluşturulabilmektedir.
Saydam olduklarından yara bölgesini gözleyebilme olanağı sağlar. Modern yarı-geçirgen yara örtüleri, genellikle poliüretanın çeşitli karışımlarından elde edilmektedir. Bu filmler sayesinde yaraya $3000 \mathrm{~g} / \mathrm{m} 2 / 24$ saat veya daha yüksek oranda nem buharı sağlanabilmektedir. Ameliyat sonrası yaralarda, yanık yaralarında, basınç yaralarının tedavisinde, ameliyat için deri alınan bölgelerde, damar içi uygulamalarında kullanılabilmektedir. Ayrıca bu örtüler, ölü dokusu içeren yaraların temizlenmesine yardımcı olmaktadır. Hafif ve esnek olup, yara yüzeyi ile iyi uyumluluk gösterdiğinden sürtünmeye karşı deri hasarını önler ve hastanın konforunu olumsuz etkilemezler. Bu örtüler; hidrojel, hidrokoloid ve alginatlarla birlikte çok sık kullanılmaktadır. Bu örtülerin dezavantajları ise; derinin aşırı nemlenmesine neden olabilmeleri, sık değiştirme zorunluluğu, uygulanabilmesi için yaranın etrafında sağlam derinin olması gerekliliğidir. [20]

\subsection{Sodyum Alginat Polimerinin Yara Örtüsü Uygulamalarında Kullanımı}

Sodyum alginat polimeride bu alanda oldukça fazla kullanılmaktadır. Alginat, yara sıvısı ile temas ettiğinde bir jel oluşturur ve ağırlığının yaklaşı 20 katı kadar sıvı emebilmektedir. Bu sebepten alginat polimerinden geliştirilen yara örtüleri Tablo 6'da görüldüğü üzere çok sslak yaralarda yani kanlı ve iltihaplı yaralarda kullanımı tercih edilmektedir. Aynı zamanda mikrop yok edici etkileri az olup, bakteriler pasif olarak jel içerisinde hapsolabilmekte ve örtü değişimi ile uzaklaştırılabilmektedir. Alginatların ağrıyı azaltıcı ve kanama durdurucu etkileri de vardır. [23]

\subsection{Hidrojel Polimerinin Yara Örtüsü Uygulamalarında Kullanımı}

Son yıllarda hidrojel maddesinin yara örtüsü uygulamalarında kullanımı ve araştırmaları yapılmaktadır. Hidrojellerin tercih edilmesinde birçok etken vardır, bunlardan biri yüksek seviyede insan vücuduna uyumlu olmasıdır. Hidrojel yara örtüleri, Tablo 6'da; yaranın akıntısını emer bu nedeniyle ıslak yani iltihaplı yaraları iyileştirmek için kullanıldığı belirtilmektedir. Bu madde sadece yaraların yüzeyi için uygundur. Bir diğer avantajı hidrojel polimerlerden elde edilen yara örtüleri şeffaf ve berraktır, bu nedenle sargı yüzeyi sargı çıkarılmadan kolayca gözlemlenebilir. Genellikle hidrojel yara örtüleri yanıklarda, cerrahi yaralarda, cilt su toplamalarında ve bası yaralarında kullanılabilir. [23] 


\subsection{Hidrokolloid Polimerinin Yara Örtüsü Uygulamalarında Kullanımı}

Hidrokolloidler yüksek miktarda su bağlayabilen yüksek molekül ağırlığı sahip makro moleküllerdir. Hidrokolloidler Tablo 6'da; küçük yanıklar, şok yaralanmaları ve çürükler gibi yüzey ülserleri için uygun biyolojik olarak parçalanabilir ve biyolojik olarak uyumlu bir yapı oluşturduğu belirtilmiştir.. Fakat hidrokolloid yara örtüleri, özellikle yaraların iyileşme oranını arttırmak için oksijene ihtiyaç duyan bir enfeksiyonu olan yaralar için uygun değildir. Bunun sebebi hidrokolloid yara örtüleri tıkayıcıdır, bu nedenle su, bakteri ve oksijenin yaraya girmesini önlerler. Ayrıca, hidrokolloidler yaranın pH'ını düşürür ve bakteri büyümesini önlemeyi kolaylaştırabilir. [23]

\section{8. İlaç Salınımlı Yara Örtüsü Uygulamaları}

İlaç salınımlı yara örtüleri, tedavi edici ajanların pansumanlara dâhil edilmesiyle, yaraların daha hızlı ve daha iyi onarılması mümkündür. Tablo 6' da ilaç salınımlı yara örtüsünün enfeksiyon kapmış yaralar üzerinde kullanıldığı belirtilmektedir. Enfeksiyon yaralarında kullanılmasının sebebi, enfeksiyonları önlemek için antibiyotikler kullanılabilmesi, hasarlı dokuları yenilemek ve ölü dokuları yaradan uzaklaştırmak için vitamin ve mineraller gibi esnek maddelerin ilaç taşıyıcılar olarak kullanılması ile yaranın iyileşebilmesi için uygun koşullar sağlanabilmesinden dolayı enfeksiyon tedavisinde kullanılmaktadır. Yara iyileşme sürecini engelleyen en önemli faktörlerden biri enfeksiyondur. Bu nedenle, yaranın yüzeyindeki mikroorganizmalardan kurtulmak için ilaç salınımlı yara örtülerinde antibiyotikler oldukça fazla kullanilmaktadır. [23]

\subsection{Yara Örtüsü Çalışmalarının Gelecekteki Beklentileri}

Kronik yaralar doktorlar, hastalar, aileler ve genel olarak insanlar için büyük zorluklardır. Yara örtüleri, iyileşmeyen ve kronik yaraların nedenlerini yönetmeye yardımcı olmak için kullanılır. Yara örtüleri çeşitli tipleri olmasına rağmen, her bir yara tipinin kendine özgü incelemesine ihtiyacı vardır. Bu alanda yapılan çalışmalar ve araştırmalar bu sebepten dolayı önem taşımaktadır.

Farklı polimer maddeler ile ilgili araştırma yapılmasının sebebi birçok farklı yara tipi olmasına dayanmaktadır. Farklı polimer maddeleri ve karışımları denenerek oluşturulan yara örtüleri belirli testlere tabii tutularak hangi yara çeşidi üzerinde kullanılabilir veya yara örtüsü statüsünde kullanılabilirliği araştırılmaktadır. Bu çalışmaların ana nedeni yaraların iyileşme süreçlerinin hızlandırılmasıdır. Günümüzde hala, diyabetik yara, venöz ayak ülseri gibi kronik yaralar için uygun bir yara örtüsü geliştirilememiştir. İlaç ile tedavi edilmeye çalışılsa da kronik yaralar genellikle tam iyileşmeye ulaşamaz.

Yara iyileşmesinde temel mekanizmalar ve mevcut yara örtüsü uygulamaları hakkında yapılan veya yapılacak çalışmalar sonucunda gerekli bilgi edinilerek, en iyi yara örtüsü seçimini kolaylaştıracaktır. Bu nedenle, hastalara ve doktorlara yardımcı olmak ve yara iyileştirme sargılarının ameliyathanelere eklenerek, yara iyileştirilmesi için gelişmiş bir tedavi seçeneği bulmak için daha fazla araştırma yapılması çok önemlidir.

Bunun yanında elde edilecek materyalin insan vücuduna uyumlu ve çevrede dönüşüme elverişli olması istenmektedir. Günümüzde insanların organik ürünlere daha çok rağbet ettiği görülmektedir. Bu davranışın ileride hele ki sağlık sektöründe daha çok artması beklenmektedir. Kullanılan materyale doğal olmayan maddeler ne kadar az dahil edilirse, insan vücuduna ürünün daha çok faydalı olacağı düşüncesi gelişmiştir. Bu çalışmada bu sebepten sentetik polimerlere nazaran biyouyumlu olan laktik asitten sentezlenen PLA polimeri kullanılmıştır. PLA polimerinin yanında yün yağı ve çörek otu yağının kullanılması ile yara örtüsüne doğal yollardan antibakteriyel özellik kazandırması amaçlanmıştır. Materyalin biyouyumlu olması dışında kolay kullanımlı olması da istenmektedir. Bunun gibi istenilen özelliklerin eldesi için yara örtüleri üzerine çalışmalar yapılmaya ve elde edilen yara örtülerinin geliştirilmesi amaçlanmaktadır.

\section{Sonuçlar ve Öneriler}

Tıbbi tekstil alanında kullanılması için üretilen yara örtüsü, belirlenen PLA polimeri ile takviye çözeltisi olarak hazırlanan çörek otu ve yün yağı farklı konsantrasyonlarda polimer çözeltisine takviye edilerek kullanılmıştır. Elde edilen farklı konsantrasyonlarda ki polimer çözeltileri elektro çekim cihazında belirli kurallar altında nanolifler haline çekilerek bir nano yüzey oluşturulmuştur. Polimer çözeltilerinin farklı konsantrasyonlarda hazırlanması ve üretim esnasında farklı voltaj değerlerinde çalışılması sonucu elektro çekim sürecine gösterdiği etkiler gözlemlenmiş, sonuçlar çıkarılmış ve üretim esnasında karşılaşılan problemler ile ilgili çözümler derlenmiştir. Ayrıca yara örtüsü numunelerine yapılabilecek test metodları modellenerek önerilerde bulunulmuştur. 


\section{1. Üretim Esnasında Karşılaşılan Problemler Çözümler}

- Üretim esnasında karşılaşılan problemlerden biri olan ağızlık ucunda çok fazla polimer madde birikmesi, bu problemin çözülebilmesi için 2 farklı yöntem mevcuttur. İlk yöntemde ağızlık ucunda fazla polimer maddenin birikmemesi için pompanın akış hızı düşürülebilir. Diğer yöntem ise akışın sağlanması için yeteri kadar voltajın ağızlığa verilmeme ihtimali olabilir, voltaj arttırılarak bu problem çözülebilir.

- Bir diğer karşılaşılan problem ise ağızlıktan toplayıcı üzerine çok cılız veya kesik kesik akışın sağlanması durumu bu problemi çözmek için akış hızı arttırılabilir. Diğer çözüm yöntemi voltaj düşürülebilir.

- Ağızlık ucunda dallanma gözlemlenmesi bir başka problemdir. Aslında gözlemlenen dallanma akışı etkilemediği sürece bir problem yaratmamaktadır. Fakat akışı etkilediği andan itibaren üretim için bir problem olmaktadır. Bu durumun çözümü için akış hızının düşürülmesi ve makinenin kontrol panelindeki $\mathrm{kV}$ tuşunun in aktif hale getirerek ağızlığın peçete ya da kuru bez yardımı ile temizlenmesi durumunda problem çözülecektir.

- Toplayıcı üzerindeki yağlı kâğıtta toplanan nanolifler de zaman zaman kalın noktalar gözlemlenmesi, bu problemin ana sebebi uygulanan voltajın jet akımı olarak tabir edilen, ağızlık ve toplayıcı arasındaki mesafede polimer çözeltisindeki çözücüleri buharlaştıracak miktarda olmamasından kaynaklanır. Bu problemin çözümü ise voltajın arttırılması ya da ortam sıcaklığının bir miktar arttırılması ile çözüme kavuşabilir.

\section{2. Öneriler}

- $\mathrm{Bu}$ ve bunun gibi karşılaşılan problemler yukarıda ki tabloda yer alan parametreler üzerinde oynanarak ve gözlem yaparak çözülebilecek etmenlerdir.

- Elektro çekim yönteminde üretim dışında çözelti hazırlamada kullanılacak polimere uygun çözelti kullanılması önemli bir noktadır. Polimer çözeltisinin son derece iyi bir şekilde karıştırılması gerekmektedir.

- Üretim esnasında ise sürekli gözlem yapılması gereklidir. Özellikle ağızlık toplayıcı bölümünün dikkat edilmesi gerekir. Karşılaşılan problemleri erken tespit etme ve müdahale etme, elde edilecek ürünün kalitesini ve kullanılabilir olmasını arttırmaktadır.

\section{Kaynakça}

[1] B. Ö, «Nanolif Üretiminde Çap Kontrolü,» Tekirdağ Namık KemalÜniversitesi, Fen Bilimleri Enstitüsü, Tekirdağ., 2013.

[2] Introduction to Technical Textill, «T1bbi Tekstillerde kullanılan hammadeler,» Medtec, 2008.

[3] Introduction to Technical Textill, «T1bbi tekstil malzemelerin özellikleri,» medtec, 2008.

[4] G. Mutlu, DOKU REJENERASYONUNDA KULLANILMAK ÜZEREETKEN MADDE YÜKLÜ NANOFIBBRILLER YAPILARIN HAZIRLANMASI VE KARAKTERIZASYONU, Ankara: Hacettepe Üniversitesi, 2014.

[5] B. Mirasoğlu, «Yara Bakım Ürünleri,» TOTBİD , cilt 14, p. 456-461, 2015.

[6] S. Altınay, «Yün Hakkında Genel Bilgiler,» 2102012. [Çevrimiçi]. Available: https://tekstilmuhendisi.wordpress.com.

[7] M. Bullivant, «Lanolin, Wool and Hand Cream,» Rough Science, 2000.

[8] F. Forouzanfar, B. Bazzaz ve Hosseinzadeh, «Nigella sativa and its constituent (thymoquinone): a review on antimicrobial effects,» National Center for Biotechnology Information, cilt 12, p. 929-938, 2014.

[9] M. Salem, «Immunomodulatory and therapeutic properties of the Nigella sativa,» PubMed, pp. 13-14, 2005.

[10] S. Darakhshan ve A. H. C. S. Ali Bidmeshki Pour, «Thymoquinone and its therapeutic potentials,» ScienceDirect, pp. 138-158, 2015.

[11] K. E.-D. D. B. Hussein El-Tahir, «The black seed Nigella sativa Linnaeus - a mine for multi cure:a plea for urgent clinical evaluation of its volatile oil.,» ScienceDirect, pp. 1-19, 2006.

[12] H. A. A. G. U. S. R. S. İ. F. S. Melek Tuter, «Partial purification of nigella sativa $\mathrm{L}$. Seed lipase and its application in hydrolytic reactions. Enrichment of $\gamma$-linolenic acid from borage oil,» SpringerLink, cilt 80, pp. 237-241, 2003.

[13] S. S. A. G. G. A. S. C. John M. Dyer, «High value oils from plants,» Wiley Online Library, 2008.

[14] 2017. [Çevrimiçi]. Available: https://okimya.com.tr/glikoller-solventler/metilen-klorit-diklorometan/.

[15] 2020. [Çevrimiçi]. Available: https://tr.wikipedia.org/ wiki/Diklorometan.

[16] 2019. [Çevrimiçi]. Available: https://tr.wikipedia.org/ wiki/Dimetilformamid.

[17] 2016. [Çevrimiçi]. Available: https://www.flokser.com.tr/ kimya/dmf/.

[18] R. Auras, L. Lim, S. Selke ve H. and Tsuji, «PLA Synthesis, Structures, Properties, Processing, and Applications,» A John Wiley \& Sons,Inc., Publication, 2010.

[19] 2015. [Çevrimiçi]. Available: https://www.acarchemicals.com/sayfalar.asp?LanguageID $=1 \& \mathrm{cid}=3 \& \mathrm{i}-$ $\mathrm{d}=13 \& \mathrm{id} 2=5757$. 
[20] A. Akgül, «En Yeni Yara Tedavileri,» 2018. [Çevrimiçi]. Available: https://www.ahmetakgul.com.tr/index.php/uzmanliklar/yara-bakimi/2128-en-yeni-yara-tedavileri.

[21] F. L. A. T. S. a. V. O. Mariana Adina Matica, «Chitosan as a Wound Dressing Starting Material:Antimicrobial Properties and Mode of Action,» PubMed, 2019.

[22] İ. A. İŞOĞLU, «Yara Örtü Malzemesi Olarak Elektroeğrilmiş PCL/PHBV Membranların Hazırlanması ve Karakterizasyonu,» Bitlis Eren Üniversitesi Fen Bilimleri Dergisi, cilt 8, no. 3, pp. 1029-1044, 2019.
[23] S. K. N. K. E. N. ,. R. Erfan Rezvani Ghomi, «Wound dressings: Current advances and future directions,» Wiley Online Library, 2019.

[24] M. Khader ve P. Eckl, Thymoquinone: an emerging natural drug with a wide range of medical applications, 2014.

[25] University of Waikato, «Wool fibre structure and properties,» 2018. [Çevrimiçi]. Available: https://www.sciencelearn.org.nz/image_maps/61-wool-fibre-structure-and-properties. 